\title{
Magyarország népegészségügyi rendszere és egészségfejlesztéssel foglalkozó szervezetei
}

\author{
The public health system and health promotion organizations of Hungary
}

\author{
Szerzők: Túri Gergőa $\bowtie$, Horváth Krisztián ${ }^{a, b}$, Kasza Katalin $^{a}$, Csizmadia Péter ${ }^{c}$ \\ a: Országos Közegészségügyi Intézet, b: Budapesti Corvinus Egyetem, \\ c: Emberi Erőforrások Minisztériuma
}

Beküldve: 2018. 03. 28

doi: 10.24365/ef.v59i2.265

\begin{abstract}
Összefoglaló: A cikk célja Magyarország népegészségügyi rendszerének és egészségfejlesztéssel foglalkozó szervezeteinek bemutatása. A cikkben röviden ismertetjük az egyes közigazgatási szintek és szervezetek főbb szerepét a népegészségügyi rendszerben, bemutatjuk a népegészségügyi rendszer kialakulását és működését befolyásoló releváns stratégiákat és jogszabályokat, valamint összefoglaljuk az országos, megyei és közösségi szinten működő szervezetek feladatait és tevékenységeit.
\end{abstract}

Kulcsszavak: népegészségügyi rendszer; egészségfejlesztés; Magyarország

Summary: The purpose of this article is to introduce the public health system and health promotion organizations of Hungary. In the article, we briefly describe the main role of the various public administration levels and organizations in the public health system, present the relevant strategies and legislation affecting the development and functioning and summarize the tasks and activities of organizations operating at national, county and community level.

Keywords: public health system; health promotion; Hungary

\section{AZ EGYES KÖZIGAZGATÁSI SZINTEK ÉS FŐBB SZERVEZETEK SZEREPE A NÉPEGÉSZSÉGÜGYI RENDSZERBEN}

Hazánkban országos szinten az egészséggel kapcsolatos jogszabály- és közpolitika-alkotás az Országgyülés, a Kormány és az Emberi Erőforrások Minisztériuma feladata [1. ábra]. Magyarország népegészségügyi rendszerében a központi kormányzat meghatározó szerepet játszik. A legfontosabb irányító intézmény az EMMI Egészségügyi Államtitkársága. 2017 első felében a korábban önálló népegészségügyi feladatokat ellátó szervezet, az Állami Népegészségügyi és Tisztiorvosi Szolgálat integrálásra került az Emberi Erőforrások Minisztériumába. Az egészségügyért felelős miniszter javaslattevő, véleményező és tanácsadó szakmai testületeként az egészségügy területén Szakmai Kollégium múködik. A szakmai kollégium tagozatokból és a tagozatok munkáját támogató tanácsokból áll. ${ }^{1}$ Fontos kutató- és tanácsadó szervezet továbbá a Népegészségügyi Képző- és Kutatóhelyek Országos Egyesülete, a Népegészségügyi Tudományos Társaság, a Magyar Higiénikusok Társasága, a Magyar Dietetikusok Országos Szövetsége és a Magyar Védőnők Egyesülete. Az Emberi Erőforrások Minisztériumához tartozó, egészségügyi és népegészségügyi területeken múködő háttérintézmény az Országos Közegészségügyi Intézet, az Állami Egészségügyi Ellátó Központ, a Nemzeti Egészségbiztositási Alapkezelő és az Országos Gyógyszerészeti és Élelmezés-egészségügyi 
Intézet. A népegészségügyi szakemberek képzésében hangsúlyos szerepet kapnak a hazai egyetemek. A Központi Statisztikai Hivatal az egészséggel kapcsolatos adatok gyűjtésében és elemzésében vállal fontos szerepet.

A népegészségügyi struktúra további szereplői az ország közigazgatási rendszerének megfelelően a megyei és közösségi szinten működő kormányhivatalok részeként tevékenykedő népegészségügyi főosztályok és osztályok.
Közösségi szinten működnek a közösségi egészségfejlesztési szolgáltatások biztosításáért felelős egészségfejlesztési irodák, valamint az egyének számára egészségfejlesztési szolgáltatások biztosításáért felelős praxisok, praxisközösségek és védőnők. A helyi önkormányzatok az egészségfejlesztéssel foglalkozó intézmények fenntartásával és a stratégiai tervek készítésével töltenek be fontos szerepet a rendszerben.

\section{1. ábra: Magyarország egészségügyi és népegészségügyi struktúrája}

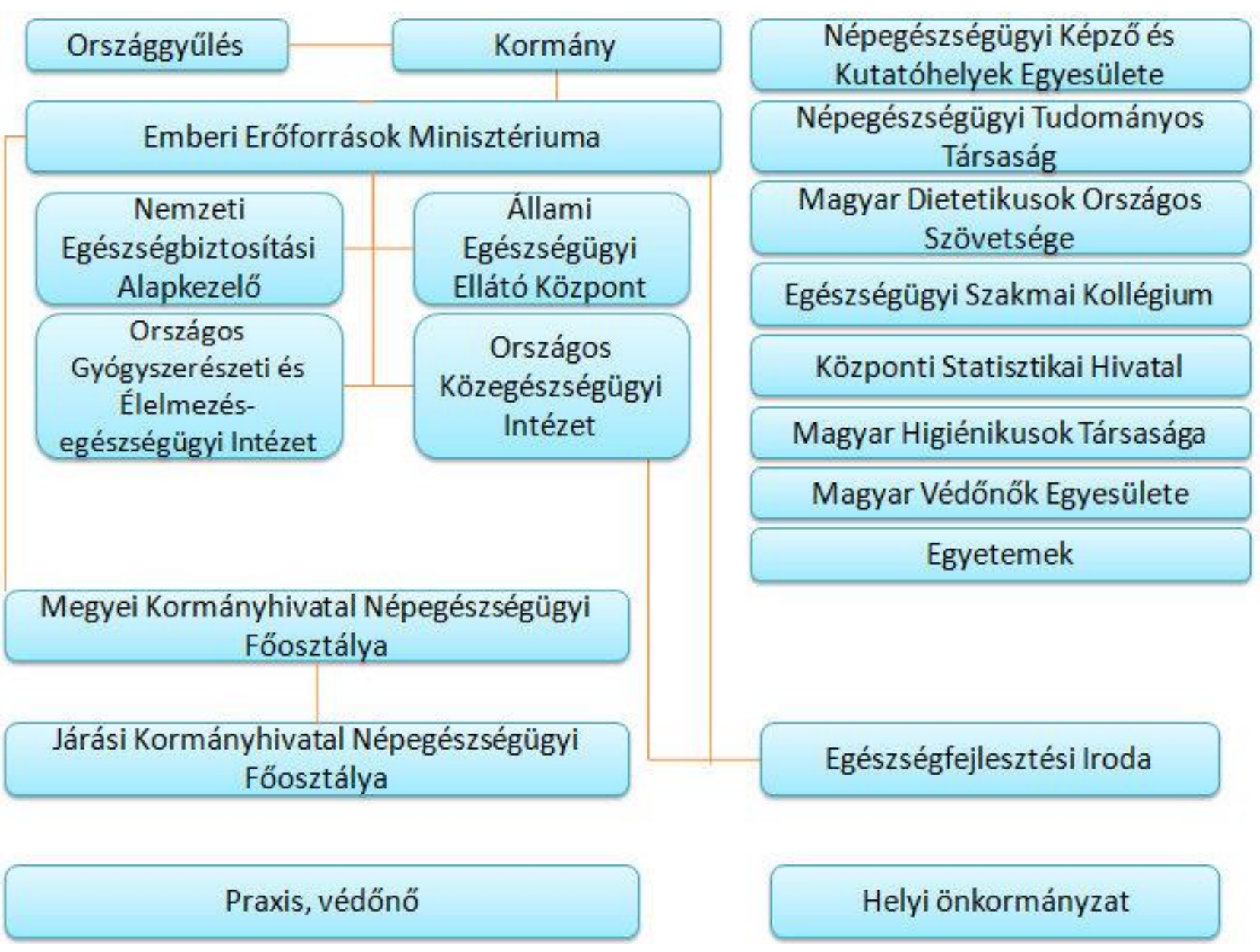

Forrás: Túri Gergő összeállítása (2018)

\section{AZ INTÉZMÉNYRENDSZER MÜKÖDÉSÉT MEG- HATÁROZÓ STRATÉGIÁK ÉS JOGSZABÁLYOK}

Az 1991. évi XI. törvény az egészségügyi hatósági és igazgatási tevékenységröl kimondja, hogy a közegészségügyi, a járványügyi, az egészségfejlesz- tési, az egészségügyi igazgatási tevékenységek szabályozása, koordinálása és felügyelete, valamint az egészségügyi ellátás felügyelete állami feladat, amit az illetékes államigazgatási szerv lát el. ${ }^{2}$

$\mathrm{Az}$ 1997. évi CLIV. törvény az egészségügyről meghatározza a népegészségügy fogalmát és az 
egészségfejlesztés céljait. A törvény meghatározza a népegészségügyhöz kapcsolódó tevékenységek csoportjait és célkitűzéseit is, valamint kimondja, hogy az egészségfejlesztési tevékenységekre vonatkozó alapvető követelmények és szükségletek biztosítása a mindenkori kormány felelőssége és kötelezettsége. A törvény hangsúlyozza továbbá a közoktatás, az egészségügyi dolgozók és a média szerepét az egészségfejlesztési ismeretek terjesztésében. $^{3}$

A 20/2012. (VIII. 31.) EMMI rendelet a nevelésioktatási intézmények müködéséről és a köznevelési intézmények névhasználatáról kimondja, hogy a közoktatási intézmények pedagógiai programjaiban jelen kell lennie az egészségfejlesztési tevékenységek teljes spektrumának. Meghatározza, hogy a közoktatásban tanulóknak rendszeresen részt kell venniük a hatékony egészségfejlesztési tevékenységekben. Az oktatási intézményeknek mindennapi múködésük során különös figyelmet kell fordítaniuk arra, hogy képesek legyenek teljes körü egészségfejlesztési tevékenységek nyújtására (pl. egészséges táplálkozás, rendszeres testmozgás, mentális egészségfejlesztés, elsősegélynyújtás, a szenvedélybetegségek megelőzése, fizikai bántalmazás és balesetek). ${ }^{4}$

Az Egészséges Magyarország stratégia 2014-2020 dokumentuma az egészségügyi ágazaton belül definiálja a népegészségügyet, és a stratégia releváns fejezete öt prioritást határoz meg: 1) a szívés érrendszeri betegségek, a cukorbetegség, a COPD, valamint a csont- és ízületi betegségek megelőzése; 2) a daganatos megbetegedések kockázatának csökkentése és a betegség korai felismerése; 3) a lelki egészség fejlesztése, fenntartása, helyreállítása, a mentális zavarok megelőzése; 4) a környezet-egészségügyi biztonság fejlesztése, valamint 5) a balesetek megelőzése, a járványügyi intézkedések megerősítése. A stratégia által kifejtett beavatkozások számos egészségfejlesztési elemet foglalnak magukban, például a tevékenységek koordinálása az alapellátási szereplők, az EFI-k, a kapcsolódó szervezetek és a kormányzati szervek között; az egészséges táplálkozás és rendszeres testmozgás támogatása; a dohányzás és a túlzott alkoholfogyasztás csökkentése; valamint az egészségfejlesztési és prevenciós szolgáltatások fejlesztése interszektoriális együttmúködések támogatása révén. ${ }^{5}$

\section{ORSZÁGOS SZINTEN MŰKÖDŐ SZERVEZETEK}

\section{Minisztérium}

Az Emberi Erőforrások Minisztériuma felelős a lakosság egészségi állapotához kapcsolódó területekért, mint például az egészségügy, a népegészségügy, a szociális ügyek, a társadalmi mobilitás és egyenlőség támogatása, a kultúra és oktatás, a sport, a család- és ifjúságügyek, a vallás és a civil szervezetek.

A minisztérium feladata a népegészségügyi stratégiák kidolgozása, a célok és prioritások meghatározása nemzeti szinten, a stratégiákban definiált célok megvalósításának koordinálása, valamint az egészség szempontjainak képviselete minden szakpolitikában. ${ }^{6}$ A minisztérium egészségügyért felelős államtitkára szakmai, politikai irányítást gyakorol a közegészségügy, környezet-egészségügy - különösen a település- és környezet-, az élelmezés- és táplálkozás-, a gyermek- és ifjúság-, valamint a sugáregészségügy és a kémiai biztonság -, járványügy és kórházhigiéné, egészségfejlesztés, valamint a szűrés- és védőoltás-koordináció területén.

A népegészségügy szempontjából kulcsszereplő az országos tisztifőorvosi feladatokért felelős helyettes államtitkár, akinek feladatai gyakorlatilag lefedik a népegészségügy területét, ellátja a járványügyi, a település- és környezet-egészségügyi, az élelmezésés táplálkozás-egészségügyi, a sugáregészségügyi, a kozmetikai termékek egészségügyi megfelelősége, a kémiai biztonsági, a gyermek- és ifjúság-egészségügyi, az egészségfejlesztési, az egészségügyi igazgatási, valamint a munkahigiéné és foglalkozásegészségügyi feladatokat. Figyelemmel kíséri és értékeli az ország közegészségügyi, járványügyi helyzetét, a népesség egészségi állapotának alakulását, továbbá az egészségi állapotot befolyásoló környezeti, társadalmi, életmódbeli tényezőket és az ezekkel kapcsolatos kutatási feladatokat, epidemiológiai és hatásvizsgálatokat, kockázatelemzést kezdeményez, illetve végez. ${ }^{7}$

\section{Háttérintézmények}

Az Országos Közegészségügyi Intézetben foglalkoznak járványügyi laboratóriumi feladatokkal, a hazai járványügyi surveillance-rendszer múködtetésével, vészhelyzeti oltóanyag-fejlesztéssel, a levegő-, víz-, 
talajszennyezettség és a sugárterhelés vizsgálatával, valamint múködtetik a foglalkozás-egészségügyi felügyeletet, népegészségügyi szűrővizsgálatokat végeznek, valamint koordinálják a folyamatban lévő, népegészségügyi témájú uniós projekteket. ${ }^{8}$

Az Állami Egészségügyi Ellátó Központ középirányítói hatás- és feladatkörébe tartozik az állami fenntartású egészségügyi intézményekhez kapcsolódó egyes tulajdonosi jogok gyakorlása. A szervezet módszertani támogatást nyújt a fenntartott intézmények számára a humánerőforrás-gazdálkodás, az egészségszervezés és a múködési hatékonyság növelése területein.

A 2015-ben végrehajtott további összevonások és átszervezések eredményeként az Állami Egészségügyi Ellátó Központ lett más, korábban független hatóságok ernyőszervezete. Ma ez a szervezet a vezető egészségügyi fenntartó is. Feladatai között szerepel a kórháztervezés, az ellátásszervezés, az egészségügyi szakemberek múködésének engedélyezése, a külső finanszírozás kezelése, a nemzeti egészségügyi stratégiák végrehajtása, valamint a nemzetközi kutatószervezetekkel való kapcsolattartás (pl. az e-egészségügy bevezetésével kapcsolatban). ${ }^{9}$

Magyarországon egybiztosítós társadalombiztosításon alapuló egészségügyi rendszer múködik, amelyben a Nemzeti Egészségbiztositási Alapkezelő finanszírozza az egészségügyi szolgáltatókat, szolgáltatásokat, és a Kormány az EMMI-n keresztül irányítja az egészségbiztosítás központi intézményét. Minden közfinanszírozott egészségügyi szolgáltatóval a NEAK áll szerződésben, továbbá pl. a háziorvosok népegészségügyi célú tevékenységeit is az Egészségbiztosítási Alapból finanszírozzák.

Az Országos Gyógyszerészeti és Élelmezés-egészségügyi Intézet feladata szakmai felügyeleti, módszertanfejlesztési és képzési tevékenységek megvalósítása élelmezés- és táplálkozástudomány területén. A szervezet fontos szerepet tölt be az egészségügyitechnológia-értékelés, a gyógyszerfelügyelet és a táplálkozással kapcsolatos kutatások területén. $^{10}$

A Központi Statisztikai Hivatal szakmailag önálló kormányhivatal. Feladata az adatgyújtések tervezése és megvalósítása, a gyújtött adatok szakmai kritériumok szerinti feldolgozása, tárolása, valamint elemzések készítése. A szervezet által készített adatbázisokat és elemzéseket számos kormányzati, gazdasági, kutató- és civil szervezettel megosztja. A szervezet számos, a lakosság egészségi állapotával, illetve azt befolyásoló tényezővel kapcsolatban gyűjt információkat, a hivatal feladata többek között az Európai lakossági egészségfelmérés megvalósítása is.

\section{Egyetemek}

Hazánkban a Semmelweis Egyetemen, a Debreceni Egyetemen, a Pécsi Tudományegyetemen és a Szegedi Tudományegyetemen képeznek népegészségügyi szakembereket, valamint az Eötvös Loránd Tudományegyetemen, a Pécsi Tudományegyetem és a Budapesti Corvinus Egyetemen egészség-gazdaságtani szakembereket.

\section{Kutató és szakmai tanácsadó szervezetek}

A Népegészségügyi Képző és Kutatóhelyek Országos Egyesülete, valamint a Népegészségügyi Tudományos Társaság és a Magyar Higiénikusok Társasága a népegészségügy területén végez kutatói, tanácsadói tevékenységeket, valamint a népegészségügyi program és stratégiaalkotás terén segíti a Kormány által képviselt, kiemelkedő népegészségügyi célok elérését. A Magyar Dietetikusok Országos Szövetsége a dietetikusok és táplálkozástudományi szakemberek képzése mellett legfontosabb tevékenységének a lakosság egészségi állapotának javítását, a jobb életminőség elősegítését, az egészségkárosító környezeti, társadalmi és egyéb hatások elleni fellépést tekinti. A Magyar Védőnők Egyesülete a lakosság magasabb szintű ellátása érdekében, egészségmegőrző, egészségnevelő, felvilágosító, anya-, gyermek-, ifjúság-, nő- és családvédelmi tevékenységet folytat.

Az Egészségügyi Szakmai Kollégium 61 tagozata fontos tanácsadói szerepet tölt be, feladatuk szakértői vélemények és tanácsok megfogalmazása egészségügyi és népegészségügyi területeken.

\section{Megyei szinten működő szervezetek}

A fővárosi és megyei kormányhivatal a Kormány általános hatáskörü területi államigazgatási szerve. Államigazgatási feladatai mellett a kormányhivatalokban működő népegészségügyi főosztályok feladatai között közegészségügyi, egészségfejlesztési, 
járványügyi, elemzési, támogatási és egészségügyi igazgatási feladatai vannak. Ellátja a megyei vezető védőnői és megyei vezető ápolónői feladatokat.

\section{Közösségi szinten működő szervezetek}

Az egészségfejlesztési irodák (EFI-k) a hazai, egészségfejlesztéssel foglalkozó szervezetek legújabb szereplői, 2013-tól kezdődően jöttek létre, összesen 61 járásban. A még nem lezárult pályázatok (EFOP, VEKOP) során újabb EFI-k jönnek létre. Az EFI-k fenntartása megoszlik az EMMI és az ÁEEK között [2. ábra]. A módszertani irányításért, támogatásáért részben a minisztérium, részben az OKI felel. Az EFIk hálózatának jövőbeni irányítási, finanszírozási feladatainak kidolgozását az EFOP 1.8.0 projekt végzi. A szervezetek múködési területe a járás, amelyhez átlagosan 50-100 ezer fő közötti lakosság tartozik, azonban a járások földrajzi kiterjedésben, urbanizációban, gazdasági fejlettségben és lakosságszámban drasztikus különbségeket mutatnak. Az egészségfejlesztési irodák lakóhelyközeli, ingyenesen igénybe vehető egészségfejlesztési szolgáltatásokat biztosítanak. Az EFI-k létrehozásának alapvető célja a szív- és érrendszeri, valamint daganatos megbetegedések prevenciójának támogatása, a korai és elkerülhető halálozás csökkentése, az egészséget meghatározó életmód, illetve az egészség-magatartást befolyásoló szokások, attitűdök javítása és a lakosság egészségtudatosságának növelése volt. Az egészségfejlesztési irodák feladata egyrészt az életmódváltó programok és közösségi szintű egészségnevelési és egészségfejlesztési programok megvalósítása különböző színtereken (települési, munkahelyi és iskolai színterek), másrészt a járásban megvalósuló egészségfejlesztési tevékenységek nyomon követése, az egészségfejlesztéssel foglalkozó szervezetek közötti együttmúködés javítása, a szervezetek hálózatba szervezése.

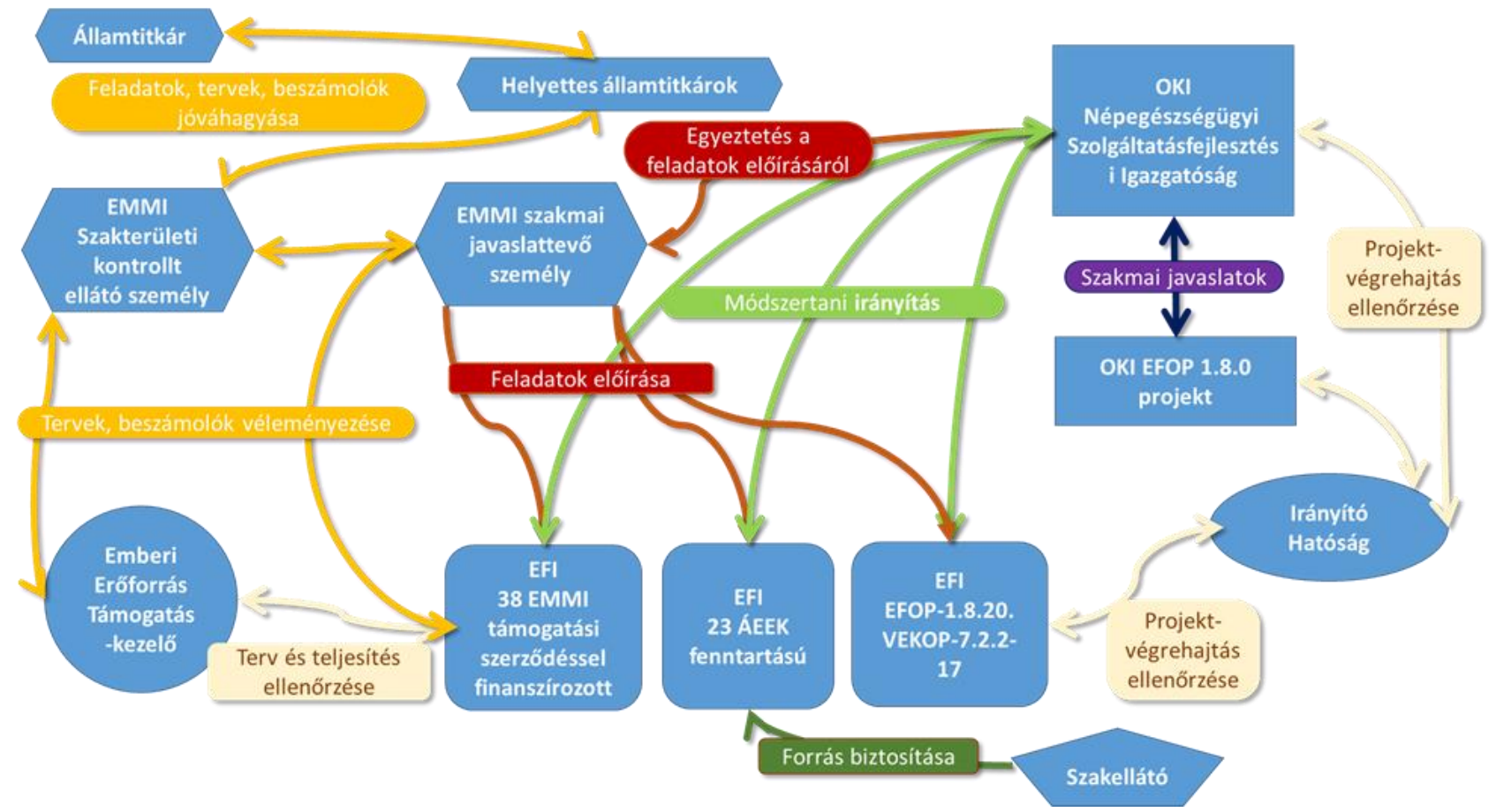

Forrás: Vitrai József ábrája 
A járási szinten múködő kormányhivatalok népegészségügyi főosztályainak jogszabályban meghatározott feladatai vannak a népegészségügy, az epidemiológia (pl. laboratóriumok üzemeltetése), az egészségfejlesztés (pl. népegészségügyi szűrések szervezése és összehangolása, nem fertőző betegségek epidemiológiája és egészséghatás-vizsgálat), az egészségügyi ellátás koordinációja területén, valamint az egészségügyi szolgáltatók felügyelete. A kormányhivatalok részt vesznek a lakosság egészségfejlesztését célzó népegészségügyi programok kidolgozásában, és irányítják, szervezik, koordinálják azok végrehajtását.

A települési szinten működő helyi önkormányzatoknak kettős szerepük van az egészségfejlesztés terén. Egyrészt ötévente kötelesek településfejlesztési tervet készíteni, amelynek tartalmaznia kell egészségfejlesztési és közösségépítési beavatkozásokat is. Másrészt a helyi önkormányzat kiemelkedő szerepet játszik az egészségfejlesztési keretrendszerben, ugyanis több olyan intézmény fenntartója, amelyek egészségfejlesztéssel foglalkoznak.

A védőnői rendszer (területi, iskolai, kórházi, Családvédelmi Szolgálat, vezető védőnők) kiemelten fontos szerepet tölt be a magzatok, gyermekek egészséges fejlődésének támogatásában, a családok, a lakosság egészségtudatosságának növelésében, az egészséget károsító szokások befolyásolásában, így a lakóhelyhez közeli megelőző népegészségügyi feladatok megvalósításában. A védőnői rendszerhez egy sajátos vezető védőnői rendszer alakult ki: a járási, fővárosi kerületi hivatalokban a járási, fővárosi kerületi vezető védőnők a területi és iskolai védőnők, a megyei kormányhivatalokban a megyei, fővárosi vezető védőnők a kórházi, a családvédelmi szolgálat és a járási vezető védőnők szakmai irányítását és szakmai felügyeletét végzik. A vezető védőnők részt vesznek az operatív múködéssel, a szakmai irányítással, a belső minőségügyi feltételek kialakításával kapcsolatos feladatokban.

A gyógyító-megelőző alapellátás keretében a háziorvosi praxisok feladatkörébe tartozik a lakosság részére nyújtott tanácsadás és az egyes népegészségügyi célú, célzott szűrővizsgálatokra való mozgósítás, a beteg vizsgálata, gyógykezelése, egészségi állapotának ellenőrzése, orvosi rehabilitációja, illetve szükség esetén szakorvosi vagy fekvőbeteg-gyógyintézeti vizsgálatra, gyógykezelésre való utalása. A háziorvos feladatkörébe tartozik továbbá olyan közegészségügyi-járványügyi és egészségfejlesztési feladatok ellátása, mint a védőoltással, a fertőző betegségekkel, személyekkel, a kórokozó-hordozókkal, ételmérgezéssel kapcsolatos feladatok, valamint az egészségnevelésben és az egészségügyi felvilágosításban való részvétel. ${ }^{11}$

A tanulmány az EFOP-1.8.0-VEKOP-17-2017-00001 Egészségügyi ellátórendszer szakmai módszertani fejlesztése projekt keretein belül készült.

\section{HIVATKOZÁSOK}

\footnotetext{
1 12/2011. (III. 30.) NEFMI rendelet az egészségügyi szakmai kollégium múködéséről

21991. évi XI. törvény az egészségügyi hatósági és igazgatási tevékenységről: https://net.jogtar.hu/jr/gen/hjegy doc.cgi?dbnum=1\&docid=99100011. TV Elérve: 2018. 03. 07.

3 1997. évi CLIV. törvény az egészségügyről. https://net.jogtar.hu/jr/gen/hjegy doc.cgi?dbnum=1\&docid=99700154.TV Elérve: 2018. 03.07.

${ }^{4}$ 20/2012. (VIII. 31.) EMMI rendelet a nevelési-oktatási intézmények múködéséről és a köznevelési intézmények névhasználatáról: https://net.jogtar.hu/jr/gen/hjegy doc.cgi?docid=a1200020.emm Elérve: 2018. 03. 07.

${ }^{5}$ Egészséges Magyarország Stratégia 2014-2020. http://www.kormany.hu/download/e/a4/30000/Eg\%C3\%A9szs\%C3\%A9ges Magyarorsz\%C3\%A1g e\%C3\%BC strat\%C3\%A9gia .pdf Elérve: 2018. 03.07.

6/2017. (IV. 3.) EMMI utasítás az Emberi Erőforrások Minisztériuma Szervezeti és Működési Szabályzatáról szóló 33/2014. (IX. 16.) EMMI utasítás módosításáról https://net.jogtar.hu/jr/gen/hjegy doc.cgi?docid=A17U0015.EMM\&timeshift=ffffff4\&txtreferer=00000001.TXT Elérve: 2018. 03. 07.
} 
${ }^{7}$ Az emberi erőforrások minisztere 7/2018. (II. 15.) EMMI utasítása az Emberi Erőforrások Minisztériuma Szervezeti és Működési Szabályzatáról szóló 33/2014. (IX. 16.)

${ }^{8}$ 385/2016. (XII. 2.) Korm. rendelet a fővárosi és megyei kormányhivatal, valamint a járási (fővárosi kerületi) hivatal népegészségügyi feladatai ellátásáról, továbbá az egészségügyi államigazgatási szerv kijelöléséről https://net.jog-

tar.hu/ir/gen/hjegy doc.cgi?docid=A1600385.KOR Elérve: 2018. 03. 07.

${ }^{9}$ OECD/European Observatory on Health Systems and Policies (2017), Magyarország: Egészségügyi országprofil 2017, State of Health in the EU, OECD Publishing, Paris/European Observatory on Health Systems and Policies, Brussels. http://dx.doi.org/10.1787/9789264285231-hu Elérve: 2018. 03. 07.

${ }^{10}$ http://www.ogyei.gov.hu/oeti/ Elérve: 2018. 03. 07.

11 4/2000. (II. 25.) EüM rendelet a háziorvosi, házi gyermekorvosi és fogorvosi tevékenységről: https://net.jogtar.hu/jr/gen/hjegy doc.cgi?docid=A0000004.EUM Elérve: 2018. 03. 07. 